DOI 10.15421/4220016

УДК 539.3

К. В. Панін, канд. фріз.-мат. наук, Я. В. Шуміхін

\title{
СКЛАДНИЙ ЗСУВ ПРУЖНО-ПЛАСТИЧНОГО БРУСА 3 МІЖФАЗНОЮ ТРІЩИНОЮ
}

Розглянуто задачу про визначення напружено-деформованого стану пружно-пластичного бруса 3 міжфазною крайовою тріщиною в умовах складного зсуву. Запропоновано числовий алгоритм розв'язання задачі, заснований на застосуванні методу скінченних елементів і диференціальнонелінійного варіанту теорії пластичності, що враховує мікродеформації (Новожилова, Кадашевіча, Чернякова). При різних схемах навантаження побудовані зони пластичності в перерізі бруса. Досліджено вплив історії навантаження та фізико-механічних властивостей матеріалів бруса на конфігурацію зон пластичності в околі вершини тріщини.

Ключові слова: складений брус; міжфразна тріщина; складний зсув; теорія пластичності, що враховує мікродеформації; метод скінченних елементів; зона пластичності.

Вступ. У зв'язку з широким застосуванням в техніці композиційних матеріалів досить актуальною є задача дослідження поведінки тріщини в області поділу двох середовищ. Багато робіт цього напрямку присвячено задачам про тріщину на границі розділу двох пружних областей. Значно менша кількість робіт присвячена дослідженню зазначеної проблеми в пружно-пластичній постановці.

Постановка задачі. Розглядається рівновага призматичного складеного бруса квадратного перерізу $(a \times a)$, який послаблений крайовою тріщиною довжиною $l=a / 2$, що проходить вздовж лінії розділу двох матеріалів (рис. 1).

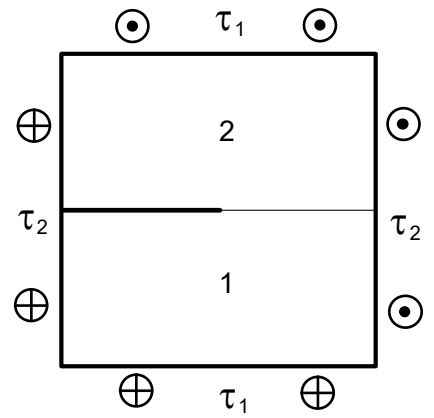

Рис. 1 - Переріз складеного бруса

(C) К. В. Панин, Я. В. Шуміхін, 2020 
Брус знаходиться під дією постійних дотичних зусиль $\tau_{1}=\tau_{1}(t)$ и $\tau_{2}=\tau_{2}(t)$, що діють по його гранях. Навантаження бруса - квазістатичне. Його матеріал - пружно-пластичний та такий, що зміцнюється. Потрібно визначити компоненти напружено-деформованого стану бруса в будь-який момент навантаження.

Для опису процесів складного пружно-пластичного деформування бруса використовуються рівняння стану теорії пластичності, що враховує мікродеформації [1]. У [2] показано, що цей диференційнонелінійний варіант теорії пластичності досить добре описує складне пружно-пластичне деформування полікристалічних тіл.

3 урахуванням того, що у разі складного зсуву траєкторії навантаження і деформування є плоскими, то визначальні співвідношення теорії пластичності, що враховує мікродеформації, приймають такий вигляд:

$$
\begin{gathered}
\dot{S}_{k}=2 G\left(\delta_{k m}-G_{k m}^{(1)}\right) \dot{\beta}_{m} \quad(k, m=1,2) ; \\
G_{k m}^{(1)}=\left(\delta_{k n}+B_{2} G_{k n}^{(2)}\right)^{-1} G_{n m}^{(2)} ; \\
G_{n m}^{(2)}=\frac{1}{B_{1}}\left(G_{n m}-\frac{\mu_{1}}{1+\mu_{1} \Omega} F_{n} F_{m}\right) ; \\
F_{k}=\int_{\Omega^{\prime}} \lambda_{k}^{\prime} d \Omega^{\prime} ; \quad G_{k m}=\int_{\Omega^{\prime}} \lambda_{k}^{\prime} \lambda_{m}^{\prime} d \Omega^{\prime} ; \quad \Omega=\int_{\Omega^{\prime}} d \Omega^{\prime},
\end{gathered}
$$

де $\dot{S}_{k}=\dot{\sigma}_{k 3}, \dot{\ni}_{k}=\dot{\varepsilon}_{k 3}-$ компоненти векторів швидкостей напружень та деформацій; $G$ - модуль зсуву; $\mu_{1}=B_{3} / B_{1} ; B_{i}$ - універсальні функції матеріалу; $\lambda_{1}^{\prime}=\cos \theta_{1}, \lambda_{2}^{\prime}=\sin \theta_{1} \cos \theta_{2}$ - напрями активного мікропластичного десормування; $d \Omega^{\prime}=\sin ^{3} \theta_{1} \sin ^{2} \theta_{2} d \theta_{1} d \theta_{2}-$ диференціальна форма “тілесний кут".

Область напрямків активного мікропластичного деформування $\Omega^{\prime}$ будується за допомогою співвідношень

$$
E\left(\lambda_{k}^{\prime}, t\right) \leq \ni_{k} \lambda_{k}^{\prime}, \quad \dot{r}_{k} \lambda_{k}^{\prime}-\frac{\mu}{1+\mu \Omega} F_{k} \dot{r}_{k}>0,
$$

де $\dot{r}_{k}=\dot{S}_{k}-B_{2} G_{k m}^{(1)} \dot{\ni}_{m}-$ компоненти вектору активних деформацій.

Інтенсивність деформацій $E\left(\lambda_{k}^{\prime}, t\right)$ визначається за допомогою формул

$$
E\left(\lambda_{k}^{\prime}, 0\right)=\varepsilon_{o}, \dot{E}\left(\lambda_{k}^{\prime}, t\right)=\left\{\begin{array}{cc}
\dot{\ni}_{k} \lambda_{k}^{\prime}, & \lambda_{k}^{\prime} \lambda_{k}=1 ; \\
B_{2} \dot{\ni}_{k}^{p} \lambda_{k}^{\prime}+\dot{\chi}, & \lambda_{k}^{\prime} \lambda_{k}= \pm 1 ; \\
\eta \dot{\ni}_{k} \lambda_{k}^{\prime}+B_{2} \dot{\ni}_{k}^{p} \lambda_{k}^{\prime}+(1+\eta) \dot{\chi}, \lambda_{k}^{\prime} \lambda_{k}=-1 ;
\end{array}\right.
$$


де $\dot{\chi}=\frac{\mu}{1+\mu \Omega} F_{k} \dot{r}_{k} ; \eta-$ універсальна функція матеріалу; $\varepsilon_{o}-$ початкова границя течії.

С урахуванням того, що визначальні співвідношення обраного варіанту теорії пластичності записуються у швидкостях, крайова задача записується також у швидкостях. Вона зводиться до побудови полів зміни напружень $\dot{\sigma}_{13}, \dot{\sigma}_{23}$, дефрормацій $\dot{\varepsilon}_{13}, \dot{\varepsilon}_{23}$ и переміщень $v_{3}$ з наступної системи диференціальних рівнянь:

$$
\frac{\partial \dot{\sigma}_{13}}{\partial x_{1}}+\frac{\partial \dot{\sigma}_{23}}{\partial x_{2}}=0, \quad \dot{\varepsilon}_{13}=\frac{1}{2} \frac{\partial v_{3}}{\partial x_{1}}, \quad \dot{\varepsilon}_{23}=\frac{1}{2} \frac{\partial v_{3}}{\partial x_{2}},
$$

до якої необхідно додати визначальні співвідношення теорії пластичності, що враховує мікродеформації (1) - (3), та крайові умови

$$
\dot{\sigma}_{k 3}=\dot{p}_{k} \text { на } S_{p} ; v_{3}=v_{30} \text { на } S_{v} \text {. }
$$

Метод розв'язування. Пружно-пластична крайова задача (1) - (5) розв'язується у приростах. Задається траєкторія навантаження в просторі зовнішнього навантаження. Далі дається приріст навантаження, і на кожному кроці приросту розшукується розв'язок задачі. Знайдені на кожному кроці розв'язки підсумовуються до тих пір, поки навантаження не досягне заданого значення. У результаті знаходяться шукані поля. Таким чином, можна записати:

$$
\begin{aligned}
& \{P\}_{i}=\{P\}_{i-1}+\{\Delta P\}_{i},\{u\}_{i}=\{u\}_{i-1}+\{\Delta u\}_{i}, \\
& \{\sigma\}_{i}=\{\sigma\}_{i-1}+\{\Delta \sigma\}_{i},\{\varepsilon\}_{i}=\{\varepsilon\}_{i-1}+\{\Delta \varepsilon\}_{i} .
\end{aligned}
$$

Тут нижні індекси відповідають номерам кроків; $\{P\},\{u\},\{\sigma\},\{\varepsilon\}-$ навантаження, переміщення, напруження та деформації, відповідно; $\{\Delta P\}$, $\{\Delta u\},\{\Delta \sigma\},\{\Delta \varepsilon\}-$ їх прирости.

Вектори $\{\Delta P\},\{\Delta u\},\{\Delta \sigma\}$ та $\{\Delta \varepsilon\}$ можуть бути представлені у вигляді

$$
\begin{aligned}
& \{\Delta P\}=\{\dot{P}\} \cdot \Delta t,\{\Delta u\}=\{v\} \cdot \Delta t, \\
& \{\Delta \sigma\}=\{\dot{\sigma}\} \cdot \Delta t,\{\Delta \varepsilon\}=\{\dot{\varepsilon}\} \cdot \Delta t,
\end{aligned}
$$

де $t$ - параметр, що монотонно змінюється.

Для розв'язування задачі на кожному кроці використовується принцип максимуму для швидкостей переміщень [3]

$$
\delta W=-\frac{1}{2} \int_{V}\left(\dot{\sigma}_{13} \delta \dot{\varepsilon}_{13}+\dot{\sigma}_{23} \dot{\varepsilon}_{23}\right) d V+\int_{S_{p_{1}}} p_{1} \delta v_{3} d S+\int_{S_{p_{2}}} p_{2} \delta v_{3} d S=0 .
$$

Для знаходження поля $\{v\}$, що задовольняє (6), застосовується метод скінченних елементів. На $i$-му кроці процесу послідовних наближень розв'язання пружно-пластичної задачі зводиться до визначення 
швидкості переміщень з глобальної системи алгебричних рівнянь вигляду

$$
\left[K\left(\left\{u_{i-1}\right\},\left\{v_{i}\right\}\right)\right]\left\{v_{i}\right\}=\left\{\dot{P}_{i}\right\} .
$$

Для розв'язання цієї системи використовується метод простої ітерації, що описується фрормулою

$$
\left\{v_{i}^{n}\right\}=\left[K_{n-1}\right]^{-1}\left\{\dot{P}_{i}\right\} .
$$

Для обчислення матриць жорсткості скінченних елементів використовується алгоритм [4], який дозволяє знизити число кратних інтегралів у визначальних співвідношеннях теорії пластичності, що враховує мікродеформації, з п'яти до двох.

Результати числового моделювання. Проведені розрахунки напружено-деформованого стану бруса з тріщиною на границі розділу двох матеріалів (рис. 1). Для першого матеріалу прийнята діаграма деформування 3, а для другого - діаграми 1-3 для різних розрахунків (рис. 2).

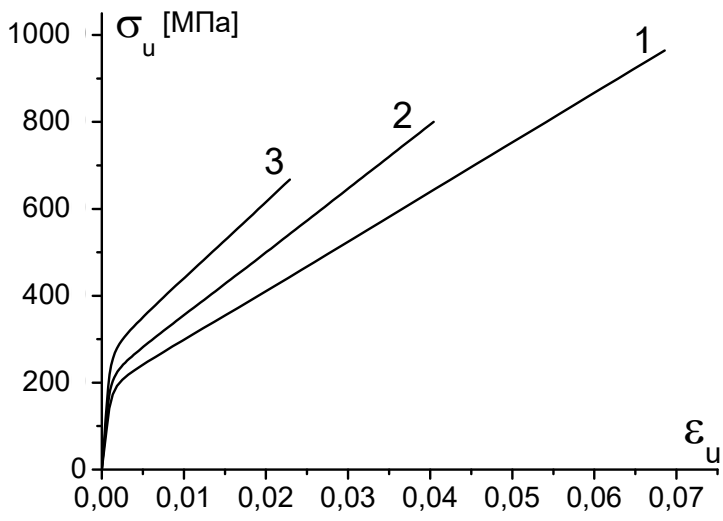

Рис. 2 - Діаграми деформування матеріалів бруса

При цьому для діаграми 1 в рамках теорії пластичності, що враховує мікродеформації, прийняті наступні константи: $G=80$ ГПа; $\tau_{s}=70$ МПа; $\varepsilon_{S}=1,31 \cdot 10^{-3} ; \quad B_{1}=2,74 ; \quad B_{2}=B_{3}=0 ; \eta=1$. Для діаграм 2 та 3 прийняті $\tau_{s}$ =90 МПа та $\tau_{s}=110$ МПа відповідно.

На рис. 3,а представлені результати розрахунку напруженодеформованого стану в перерізі бруса в залежності від властивостей другого матеріалу. Прийнята схема навантаження бруса - ОВА. При цьому в точках перетину бруса реалізується складне навантаження [4]. Для зручності порівняння показані тільки ізолінії $\sigma_{u} / \tau_{s}=1$. Суцільна лінія відповідає випадку, коли механічні властивості обох матеріалів 
описуються діаграмою деформування 3, а штрихова і пунктирні лінії коли властивості матеріалу 2 описуються діаграмами 2 і 1 відповідно.

На рис. 3,6 представлені результати розрахунку напруженодеформованого стану в перерізі бруса в залежності від виду траєкторії навантаження в просторі зовнішнього навантаження. Властивості першого і другого матеріалів описуються діаграмами 3 і 2 відповідно. Форма подання така ж, як на рис. 3 ,а. Суцільна лінія відповідає траєкторії OCA, штрихова - ODA, пунктирна - OBA.

$\mathrm{Ha}$ рис. 3,в представлені результати розрахунку напруженодеформованого стану в перерізі бруса в залежності від застосовуваного варіанта теорії пластичності. Прийнята схема навантаження бруса ОВА. Тут також показані тільки ізолінії $\sigma_{u} / \tau_{s}=1$. Матеріали - як в попередньому розрахунку. Суцільна лінія відповідає теорії пластичності, що враховує мікродеформації, штрихова - теорії течії з ізотропним зміцненням, а пунктирна лінія - деформаційній теорії.

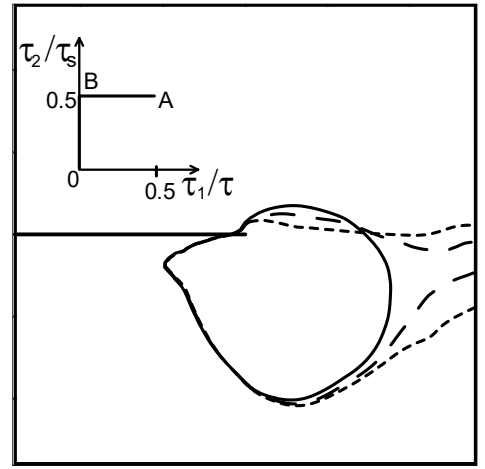

a)

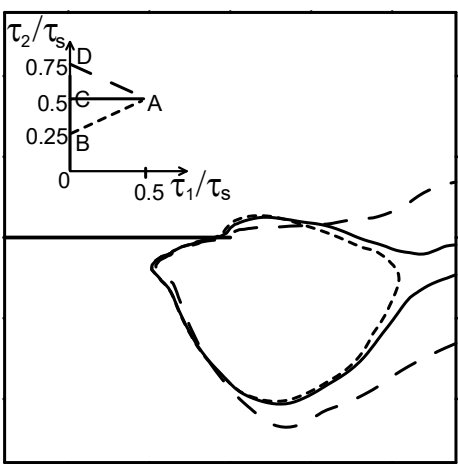

б)

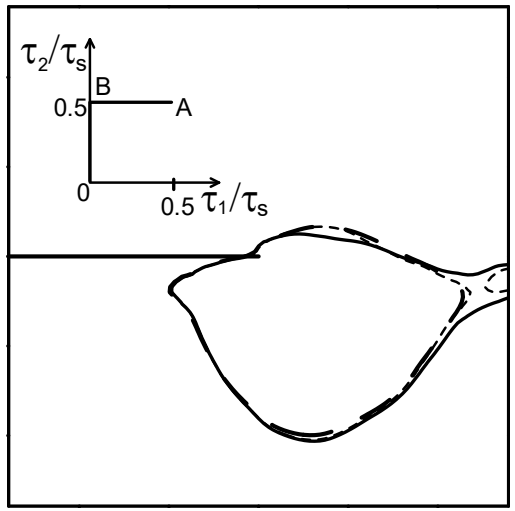

B)

Рис. 3 - Розрахунки напружено-деформованого стану у перерізі бруса 
Висновки. Отримані результати свідчать про те, що напруженодеформований стан бруса істотно залежить як від траєкторії навантаження, так і від фрізико-механічних властивостей матеріалів. Різниця в результатах, отриманих з використанням теорії пластичності, що враховує мікродеформації і теорії течії, пов'язана з тим, що остання не завжди може задовільно описати процеси складного деформування. Що стосується десоормаційної теорії, то рамки її використання обмежені простими та близькими до простих процесами навантаження. Тому спроба застосувати ії для опису складного пружно-пластичного деформування також призводить до незадовільних результатів.

Перспективним напрямком подальших досліджень $€$ застосування диференційно-нелінійних варіантів теорії пластичності для визначення напружено-десрормованого стану пружно-пластичних тіл з міжфазними тріщинами, які знаходяться в умовах складного навантаження.

\section{БІБЛІОГРАФІЧНІ ПОСИЛАННЯ}

1. Кадашевич Ю.И., Новожилов В.В., Черняков Ю.А. Теория пластичности и ползучести, учитывающая микродеформации // ПММ. 1986. Т. 50. № 6. С. 821-823.

2. Kadashevich Yu.I., Chernyakov Yu.A. Theory of plasticity taking into account micro stresses // Advanced in Mechanics. 1992. Vol.15. № 3-4. P. 3-39.

3. Черняков Ю.А. Вариационные принципы решения граничных задач теории микродеформации // Вопросы прочности и пластичности. Днепропетровск: 1997. С. $5-13$.

4. Панин К.В., Черняков Ю.А. Напряженно-деформированное состояние в окрестности вершины трещины продольного сдвига при сложном нагружении // Вопросы механики десрормирования и разрушения твердых тел. Днепропетровск: 1992. C. $39-45$.

УДК 539.3

К. В. Панин, канд. фриз.-мат. наук, Я. В. Шумихин

\section{СЛОЖНЫЙ СДВИГ УПРУГОПЛАСТИЧЕСКОГО БРУСА С МЕЖФАЗНОЙ ТРЕЩИНОЙ}

Рассмотрена задача об определении напряженно-деформированного состояния составного упругопластического бруса с межфазной краевой трещиной в условиях сложного сдвига. Предложен численный алгоритм решения задачи, основанный на применении метода конечных элементов и дифференциально-нелинейного варианта теории пластичности, учитывающей микродеформации (Новожилова, Кадашевича, Чернякова). При различных схемах внешней нагрузки построены зоны пластичности в сечении бруса. Исследовано влияние истории нагружения и физико-механических свойств бруса на конфигурацию зон пластичности в окрестности вершины межфазной трещины. 
Ключевые слова: составной брус; межфразная трещина; сложный сдвиг; теория пластичности; учитывающая микродеформации; метод конечных элементов; зона пластичности.

UDC 539.3

K. V. Panin, PhD (Phys.-Math.), Y. V. Shumikhin

\section{ELASTIC-PLASTIC BEAM WITH INTERFACIAL CRACK UNDER LONGITUDINAL SHEAR}

The problem of determining the stress-strain state of a composite elastic-plastic beam with an interfacial edge crack under complex shear conditions is considered. A numerical algorithm for solving the problem is proposed, based on the application of the finite element method and a differential-nonlinear version of the theory of plasticity, taking into account microstrains (Novozhilov, Kadashevich, Chernyakov). For various schemes of external loading, plastic zones are constructed in the section of the beam. The influence of the history of loading and the physical and mechanical properties of a beam on the configuration of plastic zones in the vicinity of the tip of an interfacial crack is investigated.

Keywords: composite beam, interfacial crack, complex shear, plasticity theory, taking into account microstrains, finite element method, plastic zone.

The equilibrium of a prismatic composite beam of square cross-section, which is weakened by an edge crack running along the line of separation of two materials, is considered.

The beam is under the action of constant tangential forces acting on its faces. The load of the beam is quasi-static. Its material is elastic-plastic and reinforcing. It is necessary to determine the components of the stress-strain state of the beam at any time during loading.

To describe the processes of complex elastic-plastic deformation of the beam, the equations of state of the theory of plasticity, which takes into account microdeformations [1], are used. In [2] it was shown that this differential-nonlinear variant of the plasticity theory describes well the complex elastic-plastic deformation of polycrystalline bodies. In it, the non-uniformity of plastic deformation due to the structure of the material is approximately taken into account by representing the tensor of plastic deformation as a sum (or in the limit as an integral) of elementary plastic deformations, each of which has its own yield surface and a system of internal microelastic forces.

Given that the defining relations of the selected variant of the theory of plasticity are written in velocities, the considered boundary problem is also written in velocities.

The trajectory of loading in space of external loading is set. Next, the load is increased, and at each step of the increase, the solution of the problem is sought. The solutions found at each step are summed until the load reaches the specified value. As a result, we obtain the required fields.

To solve the problem at each step, the principle of maximum for velocity of displacements is used [3]. 
To find a field of velocity of displacements that satisfies the principle, the finite element method is used. After assembling in the i-th step, the solution of the elastic-plastic problem is reduced to determining the velocity of displacements from the global system of nonlinear algebraic equations. To linearize this system, the method of simple iteration is used. At each step of the simple iteration method, the linear system of algebraic equations is solved using the Gaussian method.

Calculations of the stress-strain state of a beam with a crack at the interface between the two materials were performed. The calculations were carried out within the framework of the chosen version of the theory of plasticity. For comparison, similar calculations were performed using deformation theory and flow theory with isotropic hardening.

The results obtained indicate that the stress-strain state of the beam depends significantly both on the loading trajectory and on the physical and mechanical properties of materials.

The difference in the results obtained using the theory of plasticity, taking into account microstrains, and the indicated theory of flow is due to the fact that the latter cannot satisfactorily describe the processes of complex loading. As for the deformation theory, the scope of its applicability is limited to simple and close to simple loading processes. Therefore, an attempt to apply it to describe complex elastic-plastic loading also leads to unsatisfactory results.

The research results indicate that a promising area of further research is the use of differential-nonlinear variants of the theory of plasticity to determine the stress-strain state of bodies with interfacial cracks under conditions of complex loading.

\section{REFERENCES}

1. Kadashevich Yu.l., Novozhilov V.V., Chernyakov Yu.A. Теория пластичности и ползучести, учитывающая микродеформации// Applied Mechanics and Mathematics. 1986. Vol. 50. No 6. P. 821-823. (in Russian).

2. Kadashevich Yu.l., Chernyakov Yu.A. Theory of plasticity taking into account micro stresses // Advanced in Mechanics. 1992. Vol.15. No 3-4. P.3-39.

3. Chernyakov Yu.A. Variational principles for solving boundary value problems of the theory of microdeformation // Problems of strength and plasticity. Dnepropetrovsk, 1997, P. 5-13. (in Russian).

4. Panin K.V, Chernyakov Yu.A. Stress-strain state in the vicinity of the tip of a longitudinal shear crack under complex loading // Questions of mechanics of deformation and destruction of solids. Dnepropetrovsk, 1992. P.39-45. (in Russian). 